\title{
$\nabla$
}

\section{Clinical and histopathological profile of basal cell carcinoma in a population from Criciúma, Santa Catarina, Brazil} Perfil clínico e histopatológico do carcinoma basocelular em amostra populacional de Criciúma, SC, Brasil

Letícia Pangendler Peres ${ }^{1}$

Tamise da Silva Baptista ${ }^{3}$

Luiz Felipe de Oliveira Blanco ${ }^{4}$

\author{
Joana Zulian Fiorentin ${ }^{2}$ \\ Deborah Grisolia Fuzina ${ }^{3}$
}

\begin{abstract}
Basal cell carcinoma is a local, invasive epidermal neoplasia, the most common type of which is nodular basal cell carcinoma. The objective of the present study was to evaluate the occurrence of basal cell carcinoma, characterizing its distribution in accordance with patients' age, gender, the site of the lesion and its histopathological characteristics. Anatomopathology reports of cases of basal cell carcinoma diagnosed in Criciúma, Santa Catarina, Brazil between June 2005 and June 2007 were analyzed. A descriptive, observational, cross-sectional study was conducted. The majority of patients were females over 40 years of age. Most of the tumors were of the nodular type and were situated on the face. There was ulceration in $27.5 \%$, infiltration in $24.5 \%$ and invasion of the deep dermis in $61.8 \%$. Local data must be evaluated in order to emphasize the importance of early diagnosis.
\end{abstract}

Keywords: Carcinoma, basal cell; Dermatology; Neoplasms by histologic type

\begin{abstract}
Resumo: O carcinoma basocelular é uma neoplasia epidérmica invasiva local, cujo tipo mais frequente é nódulo-ulcerativo. O objetivo foi estudar a ocorrência de $\mathrm{CBC}$, caracterizando sua distribuição segundo idade, sexo, localização e características histopatológicas. Analisaram-se laudos anatomopatológicos de CBC, diagnosticados em Criciúma/SC, entre junho de 2005 e junho de 2007. Elaborou-se um estudo descritivo, observacional e transversal. Predominou após os 40 anos, no sexo feminino, do tipo nodular e localizado na face. Houve ulceração em $27,5 \%$, infiltração em $24,5 \%$, invasão de derme profunda em $61,8 \%$, entre outros. É necessário conhecer dados locais para reforçar a importância do diagnóstico precoce.

Palavras-chave: Carcinoma basocelular; Dermatologia; Neoplasias por tipo histológico
\end{abstract}

Basal cell carcinoma (BCC) is an epidermal neoplasia, the morbidity of which is related to its invasion and destruction of surrounding tissue; however, when detected early, cure rates are high. ${ }^{1,2}$

Non-melanoma skin cancer is the most common form of cancer in most regions of Brazil, particularly in the south of the country where the incidence rate is $87 / 100,000$ inhabitants. ${ }^{2}$ According to the 2010 statistics, Santa Catarina is the Brazilian state with the highest incidence of the disease, 86 cases $/ 100,000$ inhabitants. $^{2}$

The objective of the present study was to analyze anatomopathology reports of BCC diagnosed in the municipality of Criciúma over a two-year period.

This was a descriptive, cross-sectional, retrospective study. An analysis was carried out of all anatomopathology reports issued between June 2005 and June 2007 by the anatomopathology laboratory of Criciúma. Reports were included if they contained the patient's age and gender, the site of the lesion, its his-

Medical Degree awarded by the Extremo Sul Catarinense University (UNESC) - Criciúma (SC), Brazil.

Dermatologist. Professor of Dermatology, Medical School of the Extremo Sul Catarinense University (UNESC) - Criciúma (SC), Brazil. 
tological type and information regarding infiltrative tumor edges.

Of a total of 212 reports, 90 referred to males (42.5\%) and 122 to females (57.5\%). This ratio is in agreement with the trend reported in other studies. ${ }^{3,4}$

Age at diagnosis ranged from 19 to 93 years, with a predominance of the 48-58-year age group (mean age 57 years). There was no statistically significant difference between genders with respect to age $(p>0.05)$. The patients in this study were slightly younger compared to those evaluated by other authors, who have reported ages ranging from 20 to 90 years (mean age 62.1 years), with peak occurrence in the seventh decade of life.

The incidence of BCC in individuals of less than 40 years of age has increased significantly, mainly due to early diagnosis and increased exposure to sunlight. After around 20 years of exposure to the sun, a process of carcinogenesis begins, with delayed cumulative effects that become apparent at 40 to 60 years of age. ${ }^{6,7}$

Most of the lesions (61.9\%) were situated on the head, with the nose being the area most commonly affected (19.3\%). These results corroborate those of another study in which rates of $77 \%$ and $26 \%$, respectively, were reported. ${ }^{4}$ In $10.8 \%$ of cases in the present study, the lesions were situated in an unspecified region of the face, while in $9.4 \%$ of cases the lesion was on the chest.

As shown in table 1, the predominant histological type was nodular (36\%), this being the type found in 45 females and 40 males. The next most common type was the superficial basal cell carcinoma (24.1\%), recorded on 36 reports of male patients and on 21 reports of female patients. These findings are in agreement with studies in which the presence of the nodular type of basal cell carcinoma was reported in $46.3 \%{ }^{12}$ and $47 \%{ }^{8}$ of cases.

A mixed histological pattern was found in 24

TABLE 1: Distribution of the sample according to histology and gender

\begin{tabular}{lllll}
\hline & \multicolumn{2}{l}{ Gender } & & \\
\cline { 2 - 3 } Type of Tumor & Male & Female & n & $\%$ \\
\hline Superficial & 21 & 36 & 57 & $24.1 \%$ \\
Nodular & 45 & 40 & 85 & $36.0 \%$ \\
Micronodular & 11 & 23 & 34 & $14.4 \%$ \\
Cystic & 5 & 3 & 8 & $3.3 \%$ \\
Adenoid & 6 & 14 & 20 & $8.4 \%$ \\
Sclerodermiform & 6 & 12 & 18 & $7.6 \%$ \\
Pigmented & 5 & 9 & 14 & $5.9 \%$ \\
Total & 99 & 147 & 236 & $100.0 \%$ \\
\hline
\end{tabular}

reports. Reports in the literature have also registered the presence of different histopathological patterns in the same lesion.

In males, the lesion was more likely to be on the forehead or auricular region. The causal hypothesis for this is the higher frequency of baldness and short hair in men, rendering these sites more exposed to ultraviolet radiation (Table 2). In women, on the other hand, the lesions were more likely to be on the chest and arms, possibly due to the tendency of women to wear clothes with lower necklines and sleeveless blouses.

Of all the reports analyzed, ulceration was present in $27.5 \%$ and infiltration in $24.5 \%$. This is in agreement with other studies that have reported similar rates of $20 \%$ and $9 \%$, respectively. ${ }^{10}$ In the remainder of the reports, infiltration was absent in $13.2 \%$, while in $62.3 \%$ this information was missing from the report.

There was invasion of the deep dermis in 131 cases $(61.8 \%)$, of the hypodermis in $20(9.4 \%)$ and of the superficial dermis in 9 cases $(4.2 \%)$. In 52

TABLE 2: Distribution of the sample according to the site of the lesion and the patients' gender

\begin{tabular}{|c|c|c|c|c|}
\hline \multirow[b]{2}{*}{ Local } & \multicolumn{2}{|c|}{ Gender } & \multicolumn{2}{|c|}{ Total } \\
\hline & Male & Female & $\mathbf{n}$ & $\%$ \\
\hline Abdomen & 0 & 4 & 4 & $2.0 \%$ \\
\hline Auricular region & 6 & 1 & 7 & $3.3 \%$ \\
\hline Arm & 4 & 10 & 14 & $6.6 \%$ \\
\hline Philtrum & 0 & 1 & 1 & $0.5 \%$ \\
\hline Neck & 6 & 3 & 9 & $4.3 \%$ \\
\hline Clavicle & 2 & 1 & 3 & $1.4 \%$ \\
\hline Eyes & 0 & 1 & 1 & $0.5 \%$ \\
\hline Scalp & 2 & 2 & 4 & $2.0 \%$ \\
\hline Thigh & 1 & 1 & 2 & $1.0 \%$ \\
\hline Back & 9 & 8 & 17 & $8.0 \%$ \\
\hline Instep & 1 & 0 & 1 & $0.5 \%$ \\
\hline Scapular region & 0 & 1 & 1 & $0.5 \%$ \\
\hline Face (non-specific) & 11 & 12 & 23 & $10.8 \%$ \\
\hline Side of the face & 0 & 1 & 1 & $0.5 \%$ \\
\hline Forehead & 5 & 9 & 14 & $6.6 \%$ \\
\hline Lips & 0 & 5 & 5 & $2.4 \%$ \\
\hline Malar region & 6 & 2 & 8 & $3.8 \%$ \\
\hline Jaw & 0 & 1 & 1 & $0.5 \%$ \\
\hline Hands & 0 & 1 & 1 & $0.5 \%$ \\
\hline Nose & 12 & 29 & 41 & $19.3 \%$ \\
\hline Shoulders & 3 & 4 & 7 & $3.3 \%$ \\
\hline Orbital region & 2 & 1 & 3 & $1.4 \%$ \\
\hline Eyelids & 8 & 9 & 17 & $8.0 \%$ \\
\hline Legs & 0 & 1 & 1 & $0.5 \%$ \\
\hline Temple & 5 & 1 & 6 & $2.8 \%$ \\
\hline Chest & 7 & 13 & 20 & $8.9 \%$ \\
\hline Total & 90 & 122 & 212 & $100.0 \%$ \\
\hline
\end{tabular}


reports $(24.5 \%)$, there was no mention of the depth of invasion.

The edges of the tumor were infiltrated in $35.5 \%$ of cases, half of which were severely affected.

Detecting cancer at an initial phase is important for the patient's prognosis and for achieving the objective of treatment, which is a definitive cure with the best cosmetic results possible.

Some preventative measures can minimize the risk of skin cancer. These include avoiding prolonged exposure to the sun, direct exposure to toxic substances and ionizing radiation.

Knowledge of local data is important in order to make an early diagnosis, plan preventative actions and provide informative lectures for healthcare professionals, thus improving the success rate of the treatment of basal cell carcinoma.

\section{REFERENCES}

1. Telfer N.R, Colver GB, Bowers PW. Guidelines for the management of basal cell carcinoma. Br J Dermatol. 1999;141:415-423.

2. Ministério da Saúde. Secretaria de Atenção a Saúde. Instituto Nacional do Câncer. Estimativa 2010: Incidência de câncer no Brasil. Rio de Janeiro: INCA, 2009. [acesso 13 abr 2010]. Disponível em: http//:www.inca.gov.br

3. Nasser, N. Epidemiologia dos carcinomas basocelulares em Blumenau, SC, Santa Catarina, Brasil, de 1980 a 1999. An Bras Dermatol. 2005;80:363-8.

4. Mantese SAO, Berbert ALCV, Gomides MDA, Rocha A. Carcinoma Basocelular Análise de 300 casos observados em Uberlândia - MG. An Bras Dermatol. 2006;81:136-42.

5. Weshah S, Smadi R, Helalat M. Basal cell carcinoma: a retrospective analysis of 76 patients. Pak J Med Sci. 2007;23:556-60.

6. Christenson LJ, Borrowman TA, Vachon CM, Tollefson MM, Otley CC, Weaver AL, et al. Incidence of basal cell and squamous cell carcinomas is population younger than 40 years. JAMA. 2005;294:681-90.

7. Goldberg LH. Basal-cell carcinoma. Lancet. 1996;347:663-7.

8. Bandeira AM, Bandeira V, Silva JF, Mazza E. Carcinoma basocelular: estudo clínico e anatomopatológico de 704 tumores. An Bras Dermatol. 2003;78:23-34.

9. Kopke LFF, Schimidt SM. Carcinoma basocelular. An Bras Dermatol. 2002;77:24982.

10. Etter L, Cook JL. Basal cell carcinoma of the umbilicus: a case report and literature review. Cutis. 2003;71:123-6.

\footnotetext{
MAILING ADDRESS / ENDEREÇO PARA CORRESPONDÊNCIA:

Luis Felipe de Oliveira Blanco

Rua Pedro Benedet, 505, sala 306 - Centro

88801-250, Criciúma, SC, Brazil

Telephone: 554830452569

E-mail:lfobpoa@yaboo.com.br
}

How to cite this article: Peres LP, Fiorentin JZ, Baptista TS, Fuzina DG, Blanco LFO. Clinical and histopathological profile of basal cell carcinoma in a population from Criciúma, Santa Catarina, Brazil. An Bras Dermatol. 2012;87(4):657-9. 